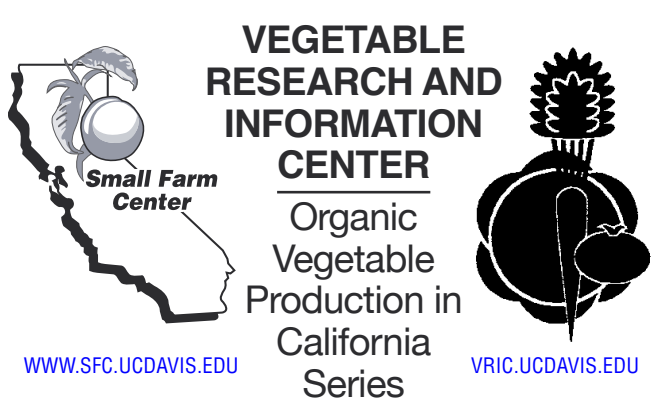

\section{ORGANIC CERTIFICATION, FARM PLANNING, MANAGEMENT, AND MARKETING}

LAURA TOURTE, University of California Cooperative Extension Farm Advisor, Santa Cruz, Monterey, and San Benito Counties; MARK GASKELL, University of California Cooperative Extension Farm Advisor, Santa Barbara and San Luis Obispo Counties; RICHARD SMITH, University of California Cooperative Extension Farm Advisor, Monterey and Santa Cruz Counties; CALVIN FOUCHE, University of California Cooperative Extension Farm Advisor, San Joaquin County; STEVEN T. KOIKE, University of California Cooperative Extension Farm Advisor, Monterey and Santa Cruz Counties; and JEFF MITCHELL, University of California Cooperative Extension Specialist, Kearney Agricultural Center, Parlier

\footnotetext{
Specific information on organic vegetable production practices in California is scarce, and growers need sound information to guide their management decisions. The Organic Vegetable Production in California Series is made up of publications written by Farm Advisors and Specialists from the University of California's Division of Agriculture and Natural Resources. Each publication addresses a key aspect of organic production practices applicable to all vegetable crops.
}

Organic vegetable production is a large and growing segment of the organic industry in California. From 1998 to 2003, farm gate sales for organic vegetables increased from $\$ 93.8$ to $\$ 154.8$ million, or roughly 65 percent. The number of production acres increased by roughly 53 percent during the same period. Expansion of the organic fresh produce segment is largely market driven and is attributed to both domestic and international demand.

Organic agricultural operations have special needs for planning, production management, and marketing beyond those of conventional farms because of limitations imposed by the terms of organic certification and registration. Certification and registration, though separate processes, are similar with respect to organic standards and requirements. Both are intended to ensure differentiation and integrity of organic production, handling, and processing.

\section{CERTIFICATION AND REGISTRATION PROCESS}

Certification, a federal legal requirement since October 2002, is administered and enforced at the national level by the USDA National Organic Program (NOP). The NOP and its regulatory agents established and promulgated National Organic Standards (NOS), which guide the production, handling, and processing of products labeled and marketed as organic (see the NOP Web site, http://www.ams.usda.gov/nop/
$\mathrm{NOP}$ /standards.html). Certification is the mechanism used to verify compliance with the NOS and is performed by accredited certifying agents. Certification is a comprehensive process whereby farming operations must document all aspects of the farm enterprise, construct an Organic Systems Management Plan, also called the Organic Farm Plan, and submit to at least one on-site inspection each year. The farm plan requires maintenance of an audit registry detailing current and anticipated crop management practices, input use, and handling. It also requires implementation, monitoring, and documentation of a long-term program for soil building, natural resource protection, and pest management.

The NOP maintains a National List of Allowed and Prohibited Substances for use (and nonuse) in organic agriculture (see the NOP Web site at http://www. ams.usda.gov/nop/NationalList/ListHome.html). All substances on the list undergo periodic review. New substances may be added as they are approved for use in organic agriculture. Therefore, materials may change and the list amended over time. Because it is each operator's responsibility to adhere to all organic standards, growers must work closely with their certifying agent to ensure compliance.

Accredited certifying agents can be state, private, and/or international agencies depending on business structure (government agency, nonprofit, or for profit) and desired market reach (domestic, international, or both). Multiple agents are accredited for

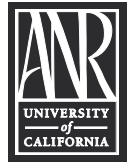

UNIVERSITY OF CALIFORNIA

Division of Agriculture and Natural Resources

http://anrcatalog.ucdavis.edu

Publication 7247 
certifying growers in California; contact information is located on the California Department of Food and Agriculture (CDFA) Web site at http://www.cdfa. ca.gov/is/fveqc/organic.htm. Accredited agents differ with respect to process and fee structure, which can vary depending on farm size and type of operation. Prior to selecting a certifying agent, growers may wish to contact more than one agent to determine differences and choose the "best fit" for their operation.

Fresh produce may be labeled and marketed as organic or USDA Organic only after completing the certification process. Part of the certification process requires passage of a period of at least 3 years prior to harvest of a crop during which time all organic standards are followed, that is, no prohibited products or processes are used. Products grown during the 3-year transitional phase may not be labeled or marketed as organic or transitional organic. However, there is no legal restriction for labeling product as "transitional." Small farms - those that have less than $\$ 5,000$ in gross sales of organic products per year-are exempt from the certification process itself, but must adhere to all practices associated with the NOS in order to label products as organic. In the past, some states, including California, have had cost-share programs to assist farmers with fees associated with certification. These programs have been contingent on USDA funding. It is not clear whether such programs will continue in the future.

Handlers and retailers of organic produce must also adhere to the standards of the NOP. Certification is mandatory for businesses that repackage or alter products or that process foods. Exemptions apply for small businesses with less than $\$ 5,000$ in gross sales per year. Some small farms and businesses may choose to become certified organic to prove product integrity and distinguish themselves in the marketplace. In other cases producers and handlers may certify with more than one certifying agent to gain competitive advantage and/or guarantee flexibility in marketing at both the domestic and international level.

Registration is a legal mechanism in the state of California that permits a grower to sell produce as organic. It is separate from certification. The regulating agency is the CDFA Organic Program, usually acting through the local county agricultural commissioner. To be in compliance with state organic standards, the CDFA requires annual registration, for which submission of the USDA Organic Farm Planwith a state registration number-is acceptable. There are strict limits on farm inputs that are allowed; the CDFA follows the same list of allowed and prohibited agricultural materials as the USDA. State registration fees apply for all organic growers, which are based on gross sales. There is no small farm exemption.
In 2004 the CDFA was approved as a State Organic Program (SOP) and now has legal authority to administer and enforce the NOP NOS. Because compliance with both federal and state requirements falls to the farm operation, it is important to maintain contact with the county agricultural commissioner's offices for current regulations. Growers may also contact the CDFA Organic Program, 1220 N Street, Room A-447, Sacramento, CA 95814 (telephone: 916-654-0919), http://www.cdfa.ca.gov/is/fveqc/organic.htm.

\section{FARM PLANNING AND MANAGEMENT}

Farm planning and management have particular implications for organic growers. Climate and soil conditions often dictate which products can be grown. The market should be an integral part of farm production planning, and promising market alternatives will affect the product mix. The experience and special skills of the grower influence the crop mix, but growers should be flexible in responding to market signals and opportunities. Options frequently expand with time as the grower gains experience in a specific field and environment.

An Organic Farm Plan, as noted above, is now required as part of the certification and registration process. The farm plan is the cornerstone of planning and decision making for organic enterprises and can aid in growers' understanding of resource allocation, financial planning, and economic sustainability. It is the primary tool for documenting compliance with the NOS. The farm plan contains the following nine sections, and can be downloaded from either the USDA Web site at http://www.ams.usda.gov/nop or the CDFA Web site at http:/ / www.cdfa.ca.gov/is/ fveqc/organic.htm.

1. General information. Asks for an informational overview of the farm or business certified or requesting certification, including operator identification, farm location, business structure, and level of knowledge of the NOS.

2. Farm plan information. Requests documentation of field histories, crops, number of acres planted or planned, and expected yields.

3. Seeds and seed treatments. Requires a list of seeds used or proposed for use, including commercially available organic seeds, and, if applicable, types of seed treatments.

4. Source of seedlings and perennial stock. Requests documentation of suppliers or producers of organically grown annual seedlings, as well as the history and management practices of nonorganic perennial planting stock. 
5. Soil and crop fertility management. Requires proactive planning, management, and documentation of soil-building practices and practices to maintain and protect natural resources, including soil and water quality.

6. Crop management. Calls for plans to manage nutrients, amendments, and soil organic matter, and to manage and prevent pest problems, including weeds, arthropods, vertebrates, and diseases. Requests documentation of crop rotations, methods and materials used or planned for use in pest control, and effectiveness of the identified practices.

7. Maintenance of organic integrity. Requires documentation of methods and practices used or planned for use to prevent contamination and commingling of organic and nonorganic production and products. Methods and practices include buffer zones and monitoring of land, equipment sanitation, and separation of harvest and postharvest products and containers.

8. Record keeping system. Requires records for all business activities related to organic planning, production, and management each year. Records must demonstrate compliance with the NOS and must be maintained for a minimum of 5 years. The system also requires tracking of organic products from field to market.

9. Affirmation. Requires signatory acknowledgement of understanding and agreement with the NOS.

Though not required for certification or registration as part of an Organic Farm Plan, growers should develop a formal business plan, which would include strategies for efficient financial management. This includes crop budgets and standard accounting documents (balance sheet and income and cash flow statements). Growers can use these documents to manage risk and identify potential hidden costs associated with organic farming, such as special facilities, equipment, and labor requirements.

\section{MARKETING}

A marketing plan is important for any farm operation, but organic vegetable growers have special marketrelated challenges. The demand for organic fresh produce varies dramatically across geographical regions and among wholesale and retail distributors within a region. Organic growers cannot look to commodity marketing agreements to aid with marketing development and promotion. Successful organic growers, especially small farmers, spend relatively large amounts of time in marketing-related activities. They keep abreast of current price trends and demand.
Several resources are available to assist growers with these activities, including the USDA Agricultural Marketing Service (http://www.ams.usda.gov), the USDA Economic Research Service (http://www.ers. usda.gov), and both state and national statistical services (http://www.cdfa.ca.gov; http://www.nass. usda.gov). The UC Small Farm Center (http://www. sfc.ucdavis.edu) can also assist growers with marketing information.

Research by the USDA Economic Research Service and the University of California identifies two current and notable market drivers within the United States: demographic changes and changes in consumer demand. The U.S. population is expected to substantially expand between 2000 and 2020, with per capita consumption of fruits and vegetables likewise increased. Preferences for such attributes as fresh organic produce are expected to rise, as is demand for specialty produce to meet ethnic and dietary preferences. Consumer-driven demand often entails a higher level of sophistication, including quality and diversity of produce. Also, a portion of overall market demand calls for increased fresh produce integrity; that is, knowing where and how produce is grown and by whom. Organic vegetables fit well into these categories.

Smaller-scale growers may be uniquely positioned to capitalize on current and projected marketplace characteristics and potential market niches. Smallscale growers can use a variety of tools to maintain economically healthy operations, including diversification of crop enterprises and varieties planted, extension of production seasons, sales of locally based and value-added products, and direct marketing fresh produce to consumers. Examples of direct sales methods include certified farmer's markets, on-farm or subscription sales, and sales to restaurants. However, many of the farmer's markets in California are full and have waiting lists. Therefore, growers who are not established in these markets must develop additional markets, grow specialized products, or enter the wholesale market stream.

The wholesale market best serves organic farm operations with larger volumes; there are growing numbers of large-scale, diversified organic operations. Some wholesalers specialize in organic products, and each broker, sales agent, or other wholesale intermediary will have minimum acceptable volumes that they can handle and still remain competitive. Some specialized organic marketing suppliers ship nationwide and even export to Europe, Asia, and elsewhere.

The market is a valuable guide for production decisions, but neither marketing nor production will be successful if they are isolated from each other. Organic production operations must work closely with sales agents or brokers who are knowledge- 
able and experienced. Poor handling of an organic product in transit by inexperienced marketers can be financially disastrous for the organic grower.

If growers experiment with or introduce new products into the marketplace-or as sales capacity for a particular product increases-farming operations must incorporate those changes into both production and market plans. Effective sales operations often expand the number of products they can handle efficiently, which in turn opens additional opportunities for growers. Ultimately, both sales and production work most effectively when crop and field planning extends as far into the future as possible.

\section{OTHER PUBLICATIONS IN THIS SERIES}

Insect Management for Organic Crops, Publication 7251, 2000. ANR CS Web site, http:/ / anrcatalog.ucdavis.edu/pdf/7251.pdf.

Plant Disease Management for Organic Crops, Publication 7252, 2000. ANR CS Web site, http://anrcatalog.ucdavis.edu/pdf/7252.pdf.

Postharvest Handling for Organic Crops, Publication 7254, 2000. ANR CS Web site, http:/ /anrcatalog.ucdavis.edu/pdf/7254.pdf.

Soil Fertility Management for Organic Crops, Publication 7249, 2000. ANR CS Web site, http:/ /anrcatalog.ucdavis.edu/pdf/7249.pdf.

Weed Management for Organic Crops, Publication 7250, 2000. ANR CS Web site, http:/ / anrcatalog.ucdavis.edu/pdf/7250. pdf.

\section{RESOURCES}

\section{Accredited Certifying Agents in California}

Accredited certifying agencies operating in California http:/ / www.cdfa.ca.gov/is/ fveqc/organic.htm

\section{State Agencies}

California Department of Food and Agriculture (CDFA)

California Organic Program

1220 N Street

Sacramento, CA 95814

Tel: (916) 445-2180

Web site: http:/ /www.cdfa.ca.gov/is/

fveqc/organic.htm
County Agricultural Commissioner's Offices (complete list): http:/ / www.cdfa.ca.gov/ exec/cl/documents/CountyCommissioner SealerContactInfo.pdf

\section{Federal Agencies}

United States Department of Agriculture (USDA)

National Organic Program

USDA-AMS-TMP-NOP

Room 4008 South Building

1400 Independence Avenue, SW.

Washington, DC 20250-0020

Tel: (202) 720-3252

Fax: (202) 205-7808

Web site: http:/ /www.ams.usda.gov/nop

\section{Research, Information and Education Support}

Alternative Farming Systems Information

\section{Center}

10301 Baltimore Avenue

USDA Beltsville, MD 20705-2351

Tel: (301) 504-6559

Fax: (301) 504-6409

Web site: http:/ / www.nal.usda.gov/afsic/

National Sustainable Agriculture Information

Center (ATTRA)

PO Box 3657

Fayetteville, AR 72702

Tel: (800) 346-9140 (English)

Tel: (800) 411-3222 (Spanish)

Web site: http:/ / www.attra.org

Organic Farming Research Foundation (OFRF)

PO Box 440

Santa Cruz, CA 95061

Tel: (831) 426-6606

Fax: (831) 426-6670

Web site: http:/ / www.ofrf.org

Organic Materials Review Institute (OMRI)

PO Box 11558

Eugene, OR 97440

Tel: (541) 343-7600

Fax: (541) 343-8971

Web site: http:/ /www.omri.org

University of California Cooperative Extension (UCCE) County Offices (complete list): http://ucanr.org/ce.cfm 
University of California Sustainable Agriculture

Research and Education Program

(UC SAREP)

University of California

One Shields Avenue

Davis, CA 95616-8716

Tel: (530) 752-7556

Fax: (530) 754-8550

Web site: http:/ / www.sarep.ucdavis.edu

\section{Marketing and Trade}

Organic Trade Association

Web site: http:/ / www.ota.com
USDA Agricultural Marketing Service

Fruit and Vegetable Market News Service http://www.ams.usda.gov/fv/mktnews. html

USDA Economic Research Service Organic Farming and Marketing Briefing Room http://www.ers.usda.gov/briefing/ Organic

USDA National Agricultural Library Organic Agricultural Products: Marketing and Trade Resources http://www.nal/usda.gov/afsic/AFSIC_ pubs/OAP/srb0301.htm

To order or obtain printed ANR publications and other products, visit the ANR Communication Services online cata$\log$ at http://anrcatalog.ucdavis.edu. You can also place orders by mail, phone, or FAX, or request a printed catalog of our products from:

University of California

Agriculture and Natural Resources

Communication Services

6701 San Pablo Avenue, 2nd Floor

Oakland, California 94608-1239

Telephone: (800) 994-8849 or (510) 642-2431

FAX: (510) 643-5470

E-mail inquiries: danrcs@ucdavis.edu

An electronic version of this publication is available on the ANR Communication Services

Web site at http://anrcatalog.ucdavis.edu.

Publication 7247

(C) 2000, 2006 by the Regents of the University of California, Division of Agriculture and Natural Resources.

All rights reserved.

The University of California prohibits discrimination or harassment of any person on the basis of race, color, national origin, religion, sex, gender identity, pregnancy (including childbirth, and medical conditions related to pregnancy or childbirth), physical or mental disability, medical condition (cancer-related or genetic characteristics), ancestry, marital status, age, sexual orientation, citizenship, or status as a covered veteran (covered veterans are special disabled veterans, recently separated veterans, Vietnam era veterans, or any other veterans who served on active duty during a war or in a campaign or expedition for which a campaign badge has been authorized) in any of its programs or activities. University policy is intended to be consistent with the provisions of applicable State and Federal laws.

Inquiries regarding the University's nondiscrimination policies may be directed to the Affirmative Action/Staff Personnel Services Director, University of California, Agriculture and Natural Resources, 1111 Franklin St., 6th Floor, Oakland, CA 94607-5201 (510) 987-0096. For a free catalog of other publications, call (800) 994-8849. For help downloading this publication, call (530) 297-4445.

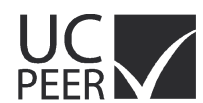

REVIEWED

This publication has been anonymously peer reviewed for technical accuracy by University of California scientists and other qualified professionals. This review process was managed by the ANR Associate Editor for Vegetable Crops.

rev-4/06-SB/CR

ISBN 978-1-60107-038-8 